\title{
DIÁLOGOS INTERDISCIPLINARES: MEMÓRIA, FICÇÃO E IDEOLOGIA EM OLGA, DE FERNANDO MORAIS
}

\author{
Sabrina Esmeris \\ Ernani Mügge**
}

RESUMO: O presente artigo apresenta uma análise da obra Olga, de Fernando Morais, entrecruzando três áreas do conhecimento: História, Literatura e Comunicação. O objetivo é estabelecer, por meio destes campos, relações entre os aspectos da memória, da ficção e da ideologia encontrados na obra. Para isso, este trabalho desenvolve diálogos entre diferentes autores, como Fernando Morais (2004), Maurice Halbwachs (2006), Patrick Charaudeau (2006), Michael Pollak (1992), Paul Ricoeur (1997), Marshall Mcluhan (2007) e Mary Del Priore (2009). Desse modo, é possível abordar processos, manifestações e produtos culturais que integram o texto em discussão por meio da interdisciplinaridade, a qual promove reflexões mediante perspectivas que podem entrar em conflito, assim como podem se somar ou se complementar.

PALAVRAS-CHAVE: Ficção; Ideologia; Memória.

\section{Introdução}

O real e o imaginário são conceitos que não se separam, muito ao contrário, se interrelacionam. $\mathrm{Na}$ condição de campos associados, interferem na construção da memória e, por consequência, instituem-se em obras ficcionais, de maneira que se possa aproximar as áreas de História e da Literatura. Portanto, distintos pontos de referência estruturam os campos de conhecimento, atravessados por rastros ideológicos cujos aspectos são estudados na área da Comunicação.

Este artigo, que tem como objetivo analisar a obra Olga, de Fernando Morais, inicia com uma abordagem sobre o conceito de memória sob a perspectiva de Maurice Halbwachs. Curiosamente, a vida deste autor e a de Olga Benario Prestes apresentam traços em comum: Halbwachs foi detido pela Gestapo após a ocupação nazista de Paris e foi

\footnotetext{
* Mestranda em Processos e Manifestações Culturais pela Universidade FEEVALE. Bolsista PROSUC/CAPES.

${ }^{* *}$ Doutor em Literatura Brasileira, Portuguesa e Luso-africana pela Universidade Federal do Rio Grande do Sul (UFRS). Professor e pesquisador na Universidade Feevale.
} 
levado para um campo de concentração; Benário, por sua vez, morreu em uma câmara de gás de um centro de confinamento de Hitler. Patrick Charaudeau contribui com a análise a partir de sua posição de que é possível identificar discursos ideológicos nas mídias. Após, volta-se ao conceito de memória, tendo como base a visão de Michael Pollak. Segue-se com Paul Ricoeur, para estabelecer cruzamentos entre História e Literatura; suas reflexões dialogam com os escritos de Mary Del Priore sobre o gênero biografia e suas relações com as áreas em questão. Ainda, tais inter-relações são complementadas pela perspectiva de Marshall Mcluhan, que, em sua Teoria do Meio, aponta para o papel do leitor como coautor de uma obra.

Este artigo visa atingir uma reflexão que integra, o máximo possível, os diferentes aspectos de uma mesma obra. As ideias contidas neste trabalho não são fixas, visto que é comum que concepções sofram modificações com o passar do tempo, variando, também, de acordo com o contexto. Os diálogos interdisciplinares estabelecidos neste texto almejam uma reflexão como em uma tessitura que constrói uma composição. Nesse caso, são questões mutantes que podem se renovar como um tecido que permite atos que o constrói, o desfaz e o refaz por conta de uma alternância entre combinação de diversos fios, gerando novas tramas.

\section{O real e o imaginário na reconstrução da vida de Olga Benario Prestes}

$\mathrm{Na}$ visão de Halbwachs (2006), o pensamento não é puramente individual, e a memória é construída de forma coletiva. Nessa ordem, para que as lembranças possam ser analisadas, é necessário considerar os contextos sociais relacionados aos fenômenos de recordação e localização, os quais são a base para a reconstrução da memória.

O trabalho de pesquisa e escrita desenvolvido pelo jornalista Fernando Morais examina determinados contextos sociais para a elaboração da biografia de Olga Benario Prestes. Assim, investiu-se em pesquisas no Brasil, viagens para à República Democrática Alemã, para Milão, Washington, Buenos Aires e em telefonemas para Moscou e Israel (MORAIS, 2004). Todos esses locais têm alguma relação com o comunismo e, assim, guardam informações sobre a ideologia, as quais podem ser obtidas por meio de relatos pessoais 
ou documentos. Esse fenômeno está de acordo com o que defende Halbwachs (2006), visto que a lembrança de um indivíduo sustenta-se nas lembranças dos grupos com os quais ele convive, ou seja, ela provém do contexto em que o ator social está inserido. Isso justifica, por exemplo, as entrevistas realizadas por Fernando Morais com Luís Carlos Prestes, com suas companheiras de prisão e outras pessoas que conviveram com Olga durante o contexto da militância comunista contra a ascensão do nazismo. O jornalista reconstrói, por meio da combinação de memórias individuais e coletivas, a história de Olga, materializando-a em um livro.

Para Halbwachs (2006), a memória é variável. Para ele, em sua versão individual, ela pode ser vista como "memória ressignificada", já que se trata de apenas um único ponto de vista sobre a memória coletiva. Ao considerar esse processo de reconstrução da memória, é questionável a primeira linha escrita logo na apresentação de Olga: "a história que você vai ler agora relata fatos que aconteceram exatamente como estão descritos neste livro: a vida de Olga Benario Prestes [...]" (MORAIS, 2004, p. 9). Essa posição se repete mais adiante, quando o autor afirma que "esse livro não é a minha versão sobre a vida de Olga Benario ou sobre a revolta comunista de 1935, mas aquela que acredito ser a versão real desse episódio" (MORAIS, 2004, p. 13). Se, anteriormente, foram encontrados pontos em comum entre Morais (2004) e Halbwachs (2006), aqui são encontradas situações discordantes, pois, para o segundo, a memória é flutuante, modificável e transformável em um estado constante. O próprio Morais (2004) parece saber disso quando, posteriormente, traz informações que contradizem a perspectiva da "verdadeira história" por ele defendida. Nesse caso, o autor menciona a palavra "reconstituição" para tratar da passagem de Olga pelo Brasil sob a perspectiva de entrevistas feitas por ele na República Democrática Alemã. O termo utilizado pelo jornalista se aproxima da ideia de "ressignificação" trazida por Halbwachs (2006), ou seja, a memória está mais próxima de uma reconstrução viabilizada por diferentes perspectivas, mesmo que relacionadas a um pensamento coletivo, do que de um fato impenetrável. Outro trecho que põe em dúvida o posicionamento de "verdade inquestionável", posto anteriormente pelo autor, é o seguinte: 
Qualquer incorreção que for localizada ao longo desta história, entretanto, deve ser debitada exclusivamente à minha impossibilidade de confrontá-la com versões diferentes. E certamente haverá incorreções, até porque eu próprio cheguei a iniciar investigações a partir de versões aparentemente verdadeiras, mas que depois seriam desmentidas por novas pesquisas ou entrevistas. Um exemplo: tenho em minhas mãos o depoimento de uma sobrevivente de Ravensbrück que jura ter visto Olga ser fuzilada naquele campo de concentração. A segurança das declarações leva-me a crer que ela de fato viu alguma mulher sendo fuzilada lá e supôs tratar-se de Olga. A verdade, no entanto, é que Olga não foi fuzilada em Ravensbrück. Outro exemplo: um eminente historiador brasileiro assegurou-me que Paul Gruber nunca passou de uma personagem de ficção inventada pelo Comintern para confundir os serviços de inteligência capitalistas. De novo, fatos, documentos e testemunhos comprovam que Gruber não só existiu em carne e osso como desempenhou papel importante no desfecho da revolta de 1935. E houve, ainda, situações em que, colocado diante de versões contraditórias sobre determinado episódio, fui levado por investigações e evidências a optar por uma delas. Não apenas como referencial, nesses casos, mas para introduzir-me por inteiro na época em que esta história se passa, recorri à extensa bibliografia que vai ao final deste volume, de importância capital para quem pretenda conhecer melhor o período. As raras passagens deste livro em que foi necessária a recriação referem-se sempre a cenários de determinados fatos - nunca a fatos em si. E, ainda assim, a recriação se deu a partir de depoimentos de testemunhas. (MORAIS, 2012, p. 13-14, grifo nosso)

Podemos constatar que o autor reconhece a possibilidade de imprecisões na obra pelo fato de, em alguns casos, não conseguir selecionar, entre as diferentes versões, a que poderia ser a mais condizente à "história real". Por essa razão, é arriscado dizer que há "uma versão verdadeira e inquestionável dos fatos", visto que a história e a memória não são fixas. Além, ele afirma que há raras recriações, as quais estão relacionadas a cenários e não a fatos. Nesse caso, ele parece estar se referindo a aspectos ficcionais, construídos juntamente à história, como os detalhes das cenas que reconstroem paisagens, ambientes, ações e sensações ou pensamentos e emoções sentidas pelos personagens, etc. A pergunta que se estabelece é a seguinte: Será que essas recriações de cenários, por partirem de uma perspectiva que se identifica com uma determinada ideologia, não interferem nas interpretações do leitor e, assim, consequentemente, em sua memória? Para refletir sobre isso, é 
possível convocar Charaudeau (2006), para quem as mídias, quando estão diante do discurso da informação, produzem efeitos no receptor que podem levá-lo a crer ou não na informação. $\mathrm{O}$ emissor faz uma aposta sobre sua validade, e cabe, ao receptor, julgar o teor do conteúdo: ele pode considerá-la imprevisível do ponto de vista factual ou integrá-la a seu sistema de conhecimentos. A informação não pode ser medida quantitativamente, pois só pode ser verificada através de seus efeitos, os quais são analisados por meio de uma séria abordagem qualitativa. Assim,

[...] a informação midiática fica prejudicada porque os efeitos visados, correspondentes às intenções da fonte de informação, não coincidem necessariamente com os efeitos produzidos no alvo, pois este reconstrói implícitos a partir de sua própria experiência social, de seus conhecimentos e crenças. Segundo o contexto no qual aparece, uma informação pode produzir um efeito de banalização, de saturação, de amálgama ou, ao contrário, de dramatização. (CHARAUDEAU, 2006, p. 59)

Como dificilmente há informações ausentes de valor de crença, certamente um biógrafo constrói a imagem do biografado a partir de seu imaginário. Diante disso, é possível afirmar que a obra Olga, ao situar-se ao lado do comunismo e opor-se ao nazifascismo, pode servir como um objeto de referência para determinados grupos, colaborando com os processos de identificação que se utilizam da memória, um fenômeno construído consciente ou inconscientemente (POLLAK, 1992). Para Pollak, a memória também está relacionada à construção da identidade individual e coletiva, sendo "um fator extremamente importante do sentimento de continuidade e de coerência de uma pessoa ou de um grupo em sua reconstrução de si” (1992, p. 5). Nesse sentido, a memória da figura de Olga, mantida por obras como a de Fernando Morais, é referência para grupos feministas como O Movimento de Mulheres Olga Benario, o qual foi criado para unir mulheres brasileiras na luta por melhores condições de vida e na defesa de causas, como igualdade salarial entre homens e mulheres e o fim da violência doméstica e sexual ${ }^{1}$. Por outro lado, a obra pode, também,

${ }^{1}$ movimentodemulheresolgabenario.blogspot.com/p/quem-somos.html. Acesso em: 25 maio. 2020. 
produzir efeitos de repulsa, indignação e ódio em grupos ligados aos ideais do anticomunismo ou do neonazismo, visto que exalta a figura de Olga. Ainda, aos leitores de opiniões indecisas, pode servir como um meio de direcionar o olhar para um ou outro lado. Ela pode, em conclusão, gerar efeitos imprevisíveis nos mais diversos grupos.

Em seu percurso investigativo, Morais enfrentou dificuldades para encontrar informações sobre a Olga no Brasil. Conforme declaração do autor, não havia quase nada sobre ela no país, sendo que nos documentos produzidos por partidos ou pesquisadores marxistas, Olga é vista apenas como a "mulher de Prestes" (2004). Isso pode ser explicado a partir da ideia de "memória seletiva" (POLLAK, 1992), a qual age sobre os fatos, determinando aquilo que vai ficar gravado ou registrado.

Várias razões podem ter contribuído para que a figura de Olga não emergisse com maior visibilidade no país, entre elas, o fato de tratar-se de uma mulher, situada em um contexto de cultural patriarcal, e de defender uma ideologia que precisava ser combatida. O próprio jornalista assinala isso, ao afirmar que Olga é um projeto que guardou "com avareza durante os anos negros do terrorismo de Estado no Brasil, quando seria inimaginável que uma história como esta passasse incólume pela censura” (MORAIS, 2004, p. 9). Assim, é necessário situá-la em um tempo em que o comunismo precisou ser silenciado.

\section{O leitor é um coautor}

A memória é socialmente construída. Para Pollak (1992), o mesmo fenômeno ocorre com a documentação, em que as fontes oral e escrita não apresentam grandes diferenças entre si no que diz respeito ao quesito veracidade. Para o teórico, a fonte escrita não deve ser vista como superior à fonte oral; as duas devem passar pelo crivo da crítica. Em Olga, Fernando Morais privilegia ambas as categorias de fontes, e reforça o posicionamento de Pollak ao revelar que, durante as entrevistas com Prestes, "foram poucos os casos de informações dadas por ele que, verificadas em processos e documentos oficiais da época, resultaram incorretas" (MORAIS, 2004, p. 10). Ao mesmo tempo, é possível inferir que ele 
tem certa desconfiança em relação aos relatos orais, por tê-las cotejado com as fontes escritas (documentos escritos). Mas o mais importante é o fato de elas terem papel importantíssimo na reconstituição da história de Olga Benário Prestes.

Outra característica da obra de Fernando Morais é a relação entre História e ficção. Nesse sentido, "o imaginário se incorpora à consideração do ter-sido, sem com isso enfraquecer seu intento realista” (RICOEUR, 1997, p. 317). Quando Morais (2004) demonstra, na apresentação de Olga, preocupação em trazer a história dela da "maneira exata como ocorreu", ele desvaloriza os aspectos ficcionais, assim como as características relacionadas ao romance e ao imaginário, as quais, segundo Ricoeur (1997), não interferem negativamente na veracidade da narrativa histórica intencionada.

Como visto anteriormente, não existe "a história", mas existem histórias. Se perspectivas individuais, conectadas a um imaginário coletivo, são base para a construção da História, há a presença de combinações de interpretações individuais e coletivas nesse processo. Nesses termos, diferentes interpretações podem surgir a partir da leitura de textos históricos, ocorrendo o mesmo com textos ficcionais, pois é o imaginário que completa o sentido. No caso de Olga, o autor informa que foi necessário recriar cenários de fatos a partir do depoimento de testemunhas. Assim, são cenários que partem da visão de um indivíduo, passam pela interpretação do autor e chegam ao leitor, o qual atribui novamente uma nova leitura à materialidade textual. Nessa lógica, um texto que se propõe imparcial, pode receber representações trágicas ou cômicas, o que o torna história ou romance: o historiador ou, nesse caso, o jornalista, "pinta" uma situação para dar "vivacidade" a um discurso (RICOEUR, 1997). Essa consideração justifica descrições que Fernando Morais traz em sua obra, as quais deixam o leitor em dúvida sobre a "veracidade" da cena ou sobre as possíveis fontes por ele consultadas. Como exemplo, há o trecho em que é descrito o término do relacionamento entre Olga e Otto: uma série de situações desencadearam o rompimento e, após a decisão final, Olga passa a sentir ciúmes pela primeira vez; envolvida por esse sentimento, ela toma o trem para Moscou (MORAIS, 2004). Apesar do entrelaçamento entre história e ficção, todavia, o projeto de representância não enfraquece, muito ao contrário, contribui para a sua realização (RICOEUR, 1997). 
Há um outro aspecto na obra de Fernando Morais que a insere também no âmbito do literário, além do histórico: as lacunas deixadas pelo autor a serem completadas pelo leitor. Diferentemente de sobrecarregar o livro com informações históricas que comprovem "cada passo" dos personagens, Morais permite que o leitor complete determinadas passagens que ficam abertas a diferentes interpretações. É o caso, por exemplo, em que o autor revive o momento em que Olga escuta seu nome na chamada para transferência para outro campo de concentração, a qual poderia indicar o caminho para a morte. Em seguida, Olga percebe duas idosas judias chorando e, ao mesmo tempo, rezando. Nesse momento, ela tenta tranquilizar as mulheres, dizendo que ela e suas colegas de prisão serão transferidas para um local melhor e que a guerra irá acabar (MORAIS, 2004). A descrição dessa cena pode sugerir diferentes leituras: uma delas, a de que Olga realmente se ilude, por um momento, na expectativa gerada pela esperança; ainda, que ela tem uma força grandiosa que a leva a consolar as pessoas, desesperadas em função da informação recebida, ao invés de ela ser consolada pelo seu triste destino. Mais adiante, quando a última carta escrita por Olga é revelada, percebe-se que ela sabe que irá morrer, pois declara à filha e ao marido que não voltará a vê-los e que estava se preparando para a morte. Ao mesmo tempo, nessa mesma carta, Olga parece esquecer, por alguns instantes, que está destinada à execução, quando, embalada pela esperança, escreve à filha mensagens que indicam um possível reencontro em que podem fazer passeios, correr ao ar livre e fazer ginástica todas as manhãs (MORAIS, 2004). Assim, permanece a dúvida: quando Olga consola as duas mulheres, ela sabe que irá morrer?

A oportunidade de o leitor tornar-se um coautor é, também, explicada pela Teoria do Meio. McLuhan (2007), ao tratar do processo de compreensão das relações entre os meios e os sentidos, apresenta os conceitos meios quentes (bot media) e meios frios (cool media). Um meio quente é aquele que prolonga um de nossos sentidos do corpo por meio de uma alta saturação de dados. Na exemplificação, ele compara uma fotografia a uma caricatura, sendo a primeira caracterizada por alta definição e, a segunda, por baixa definição, visto que esta fornece menos informação visual. Nessa ordem, os meios frios dependem do preenchimento de lacunas por parte do espectador, enquanto os meios quentes 
não dão muita abertura para a audiência completar os espaços vazios. Assim, "um meio quente permite menos participação do que um frio: uma conferência envolve menos do que um seminário, e um livro menos do que um diálogo" (MCLUHAN, 2007, p. 39). No caso de Olga, de Fernando Morais, percebe-se que, em vários momentos, o leitor é convidado a preencher lacunas, construindo, assim, os sentidos. Podemos ilustrar isso com a seguinte situação: Olga chega até o fim de sua vida demonstrando enorme preocupação com seu marido, Luís Carlos Prestes, que permanece preso no Brasil, enquanto ela sai à força do país para ser entregue a Hitler. Após a "derrota” do nazifascismo, Prestes é solto e recebe a notícia de que Olga havia morrido. Nesse momento, Morais (2004) descreve que o Capitão Prestes lê um telegrama, trazido até ele por um repórter, com a notícia da morte da companheira. Momentos depois, ele entra em um trem rumo ao Rio de Janeiro. No transporte, lê novamente a informação, então, guarda o papel no bolso. Anos se passam, e Prestes recebe, finalmente, a última carta escrita por Olga. O livro finaliza com a revelação da carta que a comunista escreve na noite que antecede sua execução, quando ainda estava em Ravensbrück. Abre-se, nesse relato, um espaço que permite ao leitor interpretar que Prestes age com indiferença ao saber da morte de Olga, por ele não demonstrar nenhuma reação. Há, entretanto, também a possibilidade de compreender a reação do personagem como resultado de um grande choque emocional. McLuhan diz que "ao ler uma estória policial, o leitor participa como coautor, simplesmente por que muita coisa é deixada fora da narrativa" (2007, p. 46). Portanto, no evento, o leitor está diante de mais de uma possibilidade, o que confirma o posicionamento citado.

\section{(In)correções biográficas}

Por ser uma obra biográfica, Olga traz outro elemento que permite relacionar história e literatura, o qual pode ser explicado pela perspectiva dos estudos de Mary Del Priore (2009). Consoante a teórica, a moda de escrever biografia histórica é recente. Ainda postula Priore que a biografia muda ao longo dos tempos, sendo que há períodos em que o efeito literário é mais importante que a exatidão das informações. Para que a biografia pudesse existir, esclarece, foi necessária a criação de uma consciência, ao passar da história, do "eu", 
ou seja, um conhecimento de indivíduo. No século XIX, a biografia serve para a construção da ideia de "nação" por meio de imortalização de heróis. Nesse período, aos poucos, a história e a literatura se separam: "Enquanto os historiadores preferiram rejeitar os ídolos individuais e os recortes cronológicos dados pelo tempo de uma existência, escritores se tornaram, então, os grandes biógrafos" (PRIORE, 2009, p. 8). Mais tarde, entretanto, "Historiadores começaram [...] a operar um discreto retorno à biografia” (PRIORE, 2009, p. 9). Em meados do século XX, a história biográfica não é devidamente valorizada, sendo que tal rejeição só se desfaz nos anos 70 e 80 . Coincidência ou não, no ano de 1982, Fernando Morais inicia as investigações para escrever Olga. Nesse período, um texto de Pierre Bourdieu surge com uma crítica sobre a subjetividade de biografias históricas, as quais tinham o potencial de reconstruir a vida de forma artificial (PRIORE, 2009). A partir disso, é possível criar uma hipótese que justifique a preocupação de Fernando Morais em trazer exatidão à obra. Assim, após o surgimento da crítica de Bourdieu, passa-se a repensar as construções biográficas, pois a "biografia não era mais a de um indivíduo isolado, mas, a história de uma época vista através de um indivíduo ou de um grupo de indivíduos" (PRIORE, 2009, p. 9). Após, surge a História Cultural e a Micro-História, as quais se preocupam com os indivíduos que são “apagados” pela história. Nesse caso, encaixa-se a biografia de Olga que, em outras épocas, não seria uma possibilidade de realização, visto que elevar a história de uma mulher não é apropriado em uma cultura machista, principalmente se essa mulher rompe com estereótipos de gênero, como é o caso da Olga.

Se antes, nesse texto, foram encontradas semelhanças entre a história de Olga e o romance, aqui, é possível estabelecer diferenças, pois "a estrutura da biografia se distingue daquela do romance por uma característica essencial: os eventos contados pela narrativa do historiador são impostos por documentos e não nascidos da imaginação" (PRIORE, 2009, p. 11). O imaginário, já abordado anteriormente, é constituído de aspectos que se diferenciam da imaginação. O historiador, ao se utilizar da imaginação para tentar reviver um acontecimento, pode viabilizar um cruzamento perigoso (PRIORE, 2009). Ao se trabalhar a ideia de cruzamento da história com ficção, cria-se oportunidades para radicalização ou 
distorção da proposta, como ocorreu no caso de "historiadores e revisionistas e negacionistas, quando se tratou de dizer, por exemplo, que não houve Holocausto de judeus, ciganos e homossexuais durante a Segunda Grande Guerra" (PRIORE, 2009, p. 13).

A partir do exposto, é valido lembrar que, por meio de um trabalho cauteloso, o cruzamento da história e da ficção pode ser um meio de relembrar e denunciar crimes, como os ocorridos durante a Segunda Guerra Mundial. Fernando Morais, ao trazer vivacidade à obra por meio das emoções sentidas pelos personagens, as quais podem ter se originado tanto no imaginário coletivo quanto na imaginação do autor, convida o leitor a estabelecer uma relação de empatia com a dor vivida por eles.

\section{Considerações finais}

O trabalho de Fernando Morais contribui, significativamente, para a formação de um ponto de vista sobre a história de Olga no Brasil, ainda mais se considerarmos que, antes de sua obra, poucas informações eram encontradas sobre ela no país. Para Pollak, "a história pode ser extremamente rica como produtora de novos temas, de novos objetos e de novas interpretações" (1992, p. 10). Assim, a obra de Morais colabora para a reconstrução da história em questão, associando-se a outras já existentes, de maneira a reforçar a pluralidade da história ou, então, das histórias.

A ficção trabalha para que determinados eventos não sejam esquecidos, pois "talvez haja crimes que não se devam esquecer, vítimas cujo sofrimento peça menos vingança do que narrativa. Só a vontade de não esquecer pode fazer com que esses crimes não voltem nunca mais" (RICOEUR, 1997, p. 327). Por outro lado, mesmo a ampla divulgação e leitura dessas obras não pode garantir que crimes não sejam repetidos, visto que uma mesma mensagem pode gerar diferentes efeitos dependendo das vivências de cada receptor McLuhan (2007).

Talvez Ricoeur (1997) esteja certo ao afirmar que se apenas a curiosidade anima, a historiografia pode ser sem memória, e a ficção é a responsável por igualar a historiografia à memória. Assim, o trabalho de trazer a memória ao povo pode, ainda, ser aprimorado, alargado e intensificado. 


\title{
INTERDISCIPLINARY DIALOGUES: MEMORY, FICTION AND IDEOLOGY IN $O L G A$, BY FERNANDO MORAIS
}

\begin{abstract}
This article presents an analysis of the work Olga, by Fernando Morais, intertwining three areas of knowledge: History, Literature and Communication. The objective is to establish, through these fields, relations between the aspects of memory, fiction and ideology found in the work. To this end, this work develops dialogues between different authors, such as Fernando Morais (2004), Maurice Halbwachs (2006), Patrick Charaudeau (2006), Michael Pollak (1992), Paul Ricoeur (1997), Marshall Mcluhan (2007) and Mary Del Priore (2009). In this way, it is possible to approach processes, manifestations and cultural products that integrate the text under discussion through interdisciplinarity, which promotes reflections through perspectives that can conflict, as well as can be added or complemented.
\end{abstract}

KEYWORDS: Fiction; Ideology; Memory.

\section{REFERÊNCIAS}

CHARAUDEAU, Patrick. Discurso das mídias. São Paulo: Contexto 2006.

HALBWACHS, Maurice. A memória coletiva. São Paulo: Centauro, 2006.

MCLUHAN, Marshall. Os meios de comunicação como extensões do homem. São Paulo: Cultrix, 2007.

MORAIS, Fernando. Olga. São Paulo: Companhia das Letras, 2004.

MOVIMENTO DE MULHERES OLGA BENARIO. Disponível em: movimentodemulheresolgabenario.blogspot.com/p/quem-somos.html. Acesso em: 25 maio. 2020.

POLLAK, Michael. Memória e identidade social. Estudos Históricos, Rio de Janeiro, vol. 5, n. 10, p. 200-212, 1992.

PRIORE, Mary Del. Biografia: quando o indivíduo encontra a história. Topoi, Rio de Janeiro, v. 10, n. 19, p. 7-16, jul./dez. 2009.

RICOEUR, Paul. O entrecruzamento da História e da ficção. In: Tempo e narrativa. Tomo III. Campinas: Papirus, 1997. p. 315-333.

Recebido em: 26/05/2012.

Aprovado em: 14/06/2020. 